\title{
Investigation of High School Students' Geometry Course Achievement According to Their Learning Styles
}

\author{
Hasan Altun ${ }^{1}$ \\ ${ }^{1}$ European University of Lefke, Gemikonağı, TRNC via Mersin 10, Turkey \\ Correspondence: Hasan Altun, Assistant Professor, Department of Elementary School Mathematics Teacher \\ Education, Dr. Fazıl Küçük Education Faculty, European University of Lefke, Gemikonağ1, TRNC via Mersin 10, \\ Turkey. E-mail: haltun@eul.edu.tr
}

\author{
Received: October 16, 2018 Accepted: November 9, $2018 \quad$ Online Published: November 21, 2018 \\ doi:10.5539/hes.v9n1p1 \\ URL: https://doi.org/10.5539/hes.v9n1p1
}

\begin{abstract}
The aim of this study is to investigate high school students' geometry course achievement according to their learning styles. $11^{\text {th }}$ grade students in İzmir constitute the general universe of the research and the sampling of the research comprises of $11^{\text {th }}$ grade students in Karabağlar district. Sampling of the research consists of total 50 high school students, determined by using appropriate sampling method. $60 \%(\mathrm{n}=30)$ of these students are female and $40 \%(n=20)$ of them are males.

Both quantitative and qualitative research methods were used depending on the main and sub-questions of the research. Kolb's Learning Style Inventory was used in order to determine the learning styles of the students.

As a result of the research, it was found out that most of the students who have diverging learning style were female students $(77.8 \%)$, most of the students who have accommodating learning style were female students $(75 \%)$, the number of male students $(47.4 \%)$ and the number of female students $(52.6 \%)$ who have assimilating learning styles are close and it was found out that, among the students who have converging learning style, female students $(55.6 \%)$ were more than males. It was determined that there was no statistically significant difference between the geometry achievement scores according to learning styles and that the students' geometric achievement means were statistically significant according to gender. It was proposed that taking learning styles into account in the regulation of education environments can help to increase achievement.
\end{abstract}

Keywords: individual differences, Kolb learning style inventory, geometry, course achievement

\section{Introduction}

Today, knowledge is very easy to reach and it is executed very quickly. Students can reach all kind of information wherever and whenever they want. Parallel to these dizzying developments, it has brought out some needs in the field of education and training and brought many innovations together. The leading one, among these needs, has been recognition of the fact that students are distinguished from each other and they have individual characteristics that contribute to their achievement. Individual characteristics are actually the individual differences that come from the birth of the individual. The students differ from one another in their approach to learning as they are different from each other. This should be taken into account in the education process. For this reason, it is necessary to establish and develop new learning and teaching environments where individual differences are at the forefront. One of the individual differences is the style of learning. Style is explained as a form, doing or expression that are unique to the individual's own life (TDK, 2005). For the first time in 1960, Rita Dunn introduced the concept of learning style into science literature. Rita Dunn (1986) defined learning style as "using some ways unique to each student while they are starting to learn, learning or remembering new and difficult information" (Boydak, 2008). According to Kolb (1984), learning style is defined as a consequence of the individual's genetic heritage, his or her past experiences and the expectations of his or her present environment from him or her. One of the courses where individual differences influence achievement is mathematics course in which abstract concepts, definitions, theorems, proofs and formulas are abundant. Because of individual differences, it cannot be expected that mathematics that is a universal language can be understood and learnt via the same style by everyone. In this context, teaching mathematics in the way by accepting that all students learn through the same style will not provide the desired benefits. 
One of the most fundamental subject areas of mathematics and one of the conceptual milestones is geometry (NCTM, 2000). We can express geometry as a subdiscipline that focuses on concepts such as point, line, plane, space, and the relationship between these concepts that are the subjects of mathematics. Students are unconsciously embracing the geometric concepts and shapes around them before they begin school life. Geometry is a science that allows students to gain the ability to see, and that allows them to reach the solution by thinking and visualizing the shape in their mind (Kaya, 1985). The students' ability to understand the concepts taught in the geometry lesson, to establish a relation between shape and its features, to understand, express geometry problems and apply the solution techniques varies due to individual differences. In this direction, the teacher needs to know which way the student prefers to learn; that means the learning styles of each student in the classroom. According to Babadoğan (2000), if the learning styles of the individuals are determined, it is easier to know which way the individual prefers to learn and what kind of instructional design should be applied. Thus, the teacher can prepare suitable teaching environment for the students.

Many researchers, working on the learning styles, have developed different learning style models. Some of those are Gregorc learning style, Dunn and Dunn learning style, Kolb learning style, McCarthy (4MAT) learning style, Felder and Silverman learning style and Grasha-Riechmann learning style.

\subsection{David Kolb Learning Style Model}

The learning style model of David Kolb is based on the experiential learning model, which is based on the learning styles of people in the 1970s (Peker, 2003). In experiential learning model, thoughts can occur repeatedly through experience, and is constantly changing. The process is more important than the production; and the aim of the education is researching during the process of information acquisition and developing skills; it is not the memorization of information (Kolb, 1984). According to this model, there are two dimensions as grasping and transformation. The experiential learning model consists of two components related to the grasping of experience: Concrete Experience (CE) and Abstract Conceptualization (AC). There are also two components related to the transformation of experience: Reflective Observation (RO) and Active Experimentation (AE) (Star, 2011). In the Kolb learning style model, concrete experience and abstract conceptualization explain how an individual perceives information; reflective observation and active experience explain how the individual operates knowledge. That is, individuals perceive information by feeling or thinking, and process the information by watching or doing things. Kolb described the Experiential Learning Model as a four-stage cycle involving Concrete Experience-CE, Reflective Observation-RO, Abstract Conceptualization-AC, Active Experimentation-AE styles (Peker, 2003, cited in Yildı, 2011). By combining these four learning styles, learning styles have been created (Kolb and Kolb, 2005, Akt. Y1ldız, 2011, 245). Kolb stated that each learning style (LS) combining with the other created new combinations; thus, more comprehensive learning styles were created. These learning styles are diverging LS, formed by CE and RO; assimilating LS, formed by AC and RO; converging LS, formed by AE and AC; and accommodating LS, formed by AE and CE (Yıldiz, 2011).

\subsection{David Kolb Learning Styles}

\subsubsection{Converging Learning Style}

It is a combination of abstract conceptualization and active life learning skills. Problem solving, decision making, logical analysis of ideas and systematic planning are the main features of those who has this learning style. Individuals in this learning style are successful in problem solving. Individuals make systematic planning when solving problems. Learning by doing is important. They are suited to professional models such as engineering, computer science, medical technology, agriculture and forestry, economics, environmental sciences (Aşkar and Akkoyunlu, 1993).

\subsubsection{Diverging Learning Style}

Concrete experience and reflective observation is a combination of learning and learning abilities. The most important feature of people with this learning style is to be aware of their ability to think, values and meanings. They are the people who revise concrete situations in many ways and organize the relationships in a meaningful way. In the case of learning, they are patient, objective, careful judges, but not being in an action. While shaping thoughts, they take their own thoughts and feelings into consideration. They are suited to professional models such as various artistic fields, psychology, nursing, social studies, theater, literature, design, media and journalism (Aşkar and Akkoyunlu, 1993).

\subsubsection{Assimilating Learning Style}

It is a combination of abstract conceptualization and reflective observation learning abilities. The most prominent feature of the people with this learning style is creating conceptual models. When they learn 
something, they focus on abstract concepts and ideas. They are committed to professional models such as physics, biology, mathematics, educational sciences, sociology, law, and theology (Aşkar and Akkoyunlu, 1993).

\subsubsection{Accomodating Learning Style}

Concrete experience and active experimentation are a combination of their learning abilities. Planning, executing decisions and participating in new experiences are key features of the people with this learning style. In the case of learning, individuals are open minded and they adapt to change easily. They are compatible with the areas such as management, public finance, education management, marketing, public administration, human resources etc. (Aşkar and Akkoyunlu, 1993).

\subsection{The Importance of Research and Its Purpose}

In geometry teaching, the arrangement of teaching and learning environments by considering the learning styles of the students will enhance the quality of geometry teaching. It will help to overcome the negative attitudes and behaviors that students have developed against geometry lessons. In this direction, by considering learning styles, suggestions towards improving the academic achievement of students can be proposed. Under the light of this information, the main purpose of this research is to investigate high school students' geometry course achievements according to the learning styles. Within the scope of this purpose, the following questions will be tried to be answered.

\subsubsection{Sub-Questions}

1. How is the distribution of learning styles of high school students according to gender?

2. Is there a statistically significant difference between geometry course achievements of high school students according to their learning styles?

3. Is there a statistically significant difference between geometry course achievements of high school students according to gender?

4. What are the opinions of math teachers about learning styles?

\section{Method}

\subsection{Research Design}

This study that aims to investigate the students' geometry course achievement according to their learning styles is a descriptive research within the relational survey model. Survey models are research approaches that aim to describe a present or past situation as it exists. The event, individual or thing that is the subject of the research is is tried to be defined in its own conditions and as is (Karasar, 2007: 77).

\subsection{Universe and Sampling}

Eleventh grade students in İzmir constitute the general universe of the research and the sampling of the research comprises of eleventh grade students studying at a state high school in Karabağlar district. Sampling of the research consists of total 50 high school students, determined by using appropriate sampling method. $60 \%(\mathrm{n}=30)$ of these students are female and $40 \%(\mathrm{n}=20)$ of them are males. The distribution of the students constituting the sample according to gender is given in Table 1 .

Table 1. The Distribution of the Students According to Gender

\begin{tabular}{lll}
\hline Gender & $\mathrm{n}$ & $\%$ \\
\hline Female & 30 & 60 \\
Male & 20 & 40 \\
Total & 50 & 100 \\
\hline
\end{tabular}

Note. $\mathrm{n}=$ Sampling number

\subsection{Data Collection Tool}

In this study, the third version of Kolb Learning Styles Inventory (KLSI-3) developed by David Kolb was used to determine learning styles of students. In the first version of the inventory, four words in nine lists are arranged so as to reveal the learning preferences of the individuals. The scores obtained from the scale are classified as diverger, assimilator, converger, and accommodator depending on learning preferences as concrete experience-CE, reflective observation- $\mathrm{RO}$, abstract conceptualization-AC, and active experimentation-AE according to Kolb's Experiential Learning Model (Kolb, 1984). The studies that have been done reveal that the reliability studies on this first version of the inventory should be continued. Inventory was renewed in 1985 by creating a new format and scoring system (Kolb and Kolb, 2005b). This second version of the inventory consists 
of 12 complementary type items. In order to increase the comprehensibility of the items, sentences were used instead of the words in the first version, and the statements were tried to be embodied. Surveys have shown that the reliability coefficient and internal consistency of the inventory are significantly higher than the previous version, and that it can be used to determine individuals' learning styles. This second version of the inventory was translated into Turkish by Aşkar and Akkoyunlu (1993), and validity and reliability studies were carried out. As a result of the studies, the reliability coefficients (Cranbach) of the four dimensions of the learning style inventory were found to vary between .73 and .83 . Accordingly, the reliability coefficient has been at the satisfactory level and it is concluded that KLSI can be applied in Turkey. In the research, the reliability of the inventory administered in order to determine the learning styles of the students was found to be between .70 and .85. Three mathematics teachers working in Anatolian High School were asked for their opinions about learning styles by using semi-structured face-to-face interview technique. Semi-structured face-to-face interviews allow the participants to tell the world that they perceive with their own thoughts. Most of the questions should be open-ended. In such interviews, either each question should consist of flexible clauses or the interview should be prepared in different structured techniques (Merriam, 2013).

\subsection{Analysis of Data}

The data obtained via Kolb's learning style inventory implemented to the students and end-of-year achievement scores for geometry course were analyzed by using the SPSS package program. Accordingly, from this descriptive statistical data; mean, standard deviation, frequency and percentage, F and t-test were used. The significance level in the study was accepted as 0.05 .

\section{Results}

3.1 The First Sub-question of the Research was Expressed as "How is the distribution of Learning Styles of High School Students according to Gender?"

Percent distribution of students with assimilating learning styles according to gender is given in Table 2 .

Table 2. Percent Distribution of Students with Assimilating Learning Styles

\begin{tabular}{lll}
\hline Gender & $\mathrm{n}$ & $\%$ \\
\hline Female & 9 & 47.4 \\
Male & 10 & 52.6 \\
Total & 19 & 100.0 \\
\hline
\end{tabular}

It is seen in the Table 2 that the numbers of male and female students with assimilating learning styles are close to each other. The most prominent feature of the people who have this learning style is to create conceptual models. Percent distribution of students with converging learning styles according to gender is given in Table 3 .

Table 3. Percent Distribution of Students with Converging Learning Styles

\begin{tabular}{lll}
\hline Gender & $\mathrm{n}$ & $\%$ \\
\hline Female & 8 & 44.4 \\
Male & 10 & 55.6 \\
Total & 18 & 100.0 \\
\hline
\end{tabular}

It is seen in the Table 3 that among the students who have converging learning style, female students (55.6\%) were more than males. The most prominent characteristics of students with this learning style are problem solving, decision making, logical analysis of ideas and systematic planning. Güven (2003) examined the learning styles of teacher candidates in his thesis study named "Investigation of Learning Styles of Teacher. Candidates in Physics Teaching". As a result of the research, it was seen that the physics teacher candidates prefer the "Converging" learning style.

Percent distribution of students with accommodating learning styles according to gender is given in Table 4

Table 4. Percent Distribution of Students with Accommodating Learning Styles

\begin{tabular}{lll}
\hline Gender & $\mathrm{n}$ & $\%$ \\
\hline Female & 1 & 25 \\
Male & 3 & 75 \\
Total & 4 & 100.0 \\
\hline
\end{tabular}


It is seen in the Table 4 that among the students who have accommodating learning style, female students (55.6\%) were more in numbers. The most prominent features of students with this learning style are planning, making decisions and taking part in new experiences. Percent distribution of students with diverging learning styles according to gender is given in Table 5.

Tablo 5. Percent Distribution of Students with Diverging Learning Styles

\begin{tabular}{lll}
\hline Gender & $\mathrm{n}$ & $\%$ \\
\hline Female & 2 & 22.2 \\
Male & 7 & 77.8 \\
Total & 9 & 100.0 \\
\hline
\end{tabular}

As is seen in Table 5, it was found out that most of the students who have diverging learning style were female students (77.8\%). The most distinctive features of students with this learning style are their awareness of their ability to think, values and meanings. In this case, it can be said that the thinking skills of female students are higher than male students.

\subsection{The Second sub-question of the Research Was expressed As "Is There A Statistically Significant Difference} Between Geometry Course Achievements of High School Students according to Their Learning Styles?"

Distribution of score means of students' geometry course achievements is given in Table 6 .

Table 6. Distribution of Score Means of Students' Geometry Course Achievements

\begin{tabular}{lclll}
\hline Learning Style & $\mathrm{n}$ & $\overline{\mathrm{x}}$ & $\mathrm{Sd}$ & $\mathrm{Se}$ \\
\hline Assimilating & 19 & 66.052 & 21.054 & 4.830 \\
Converging & 18 & 65.500 & 19.921 & 4.695 \\
Accommodating & 4 & 61.250 & 14.361 & 7.180 \\
Diverging & 9 & 72.222 & 20.933 & 6.977 \\
Total & 50 & 66.580 & 19.834 & 2.804 \\
\hline
\end{tabular}

Note. $\overline{\mathrm{x}}=$ Mean, $\mathrm{n}=$ Sampling number, $\mathrm{Sd}=$ Standard Deviation, $\mathrm{Se}=$ Standard Error

When the Table 6 that shows the distribution of the score means of students' geometry course achievements according to learning styles is analysed, it is seen that the students with the diverging learning style have higher mean $\left(\mathrm{x}^{-}=72.222\right)$. The most important characteristics of students in this learning style is their ability to think. It is expected that students with this style of learning will be successful in a course in which the ability to think is on the top level as geometry. In Table 6, it is seen that the students with the diverging learning style have a higher mean of geometry course achievement than the students with the other styles. When the occupational groups of individuals with this style are examined, it is often seen that visuality and aesthetics are on the foreground as in design, media, literature, psychology and newspapers. Geometry is also a course that has aesthetic and visuality in itself. In geometry lesson, it is important to be able to see and express the features of shapes and relationships between these features and use them in problem solving. Students with diverging learning style are those who revise concrete situations in many respects and organize relationships in a meaningful way (Aşkar and Akkoyunlu, 1993).

The students with assimilative learning style have the second highest mean of the geometric course means $(\bar{x}=$ 66.052). The most distinctive feature of the students with this learning style are understanding and creating conceptual models. In a course such as geometry in which conceptual models, definitions and terms are intertwined, the fact that students with this learning style have a high achievement in geometry courses supports the characteristics of students with this style. Having abstract concepts in mathematics and geometry courses makes these courses difficult and incomprehensible among students. Focusing on abstract concepts and ideas, one of the characteristics of students with assimilative learning style, shows that students with assimilative learning style can understand and learn the geometry course.

The main characteristics of individuals with converging learning style are often problem solving, decision making, logical analysis of ideas and systematic planning. Individuals in this learning style are successful in problem solving. Individuals make systematic planning while solving problems. Learning by doing is important (Aşkar and Akkoyunlu, 1993). Geometry is a course that includes almost all of the features of the students with converging learning style. When we look at the mean of students with converging learning style $\left(\mathrm{x}^{-}=65.500\right)$, it does not support this situation. It can be said that this is due to the geometry education designed without taking 
the learning styles which is one of the individual differences of the research subjects into consideration. Students can not demonstrate the actual performance and success, fully, in the geometry course in which they show the characteristics of the learning style that they possess.

The students with accommodating learning style that is the combination of the concrete experience and the active experimentation learning styles have the lowest geometry course achievement means $\left(\mathrm{x}^{-}=61.250\right)$. In geometry lessons, students often encounter problems. While solving the problems, they organize the given information about the problem, and try to reach the result by solving the problems systematically. Individuals with this learning style have features such as planning, making decisions and taking part in new experiences (Aşkar and Akkoyunlu, 1993).

Geometry is a course in which the ability to think independently, to make decisions by adapting to new and different situations come to the forefront. Individuals in this style are open-minded and adapt easily to change (Aşkar and Akkoyunlu, 1993). In terms of the characteristics displayed by the students in this style, the mean of geometry course achievement must be high. Knowing the learning styles preferred by the students will contribute to their achievement. Gülten and Gülten (2003) investigated the relationship between high school $2^{\text {nd }}$ grade students' scores and their learning styles in a study called "The Relationship Between Geometry Course Scores and Learning Styles of High School 2 nd Grade Students". As a result of the research, it was found that the relationship between students' geometry course achievement scores and visual learning style is strong. Peker (2005) investigated the relationship between learning styles and mathematical achievements of students who got into primary school mathematics teaching department in the study called "The Relationship Between Learning Styles and Mathematical Achievement of the Students Who Got into Primary School Mathematics Teaching Department". Kolb Learning Style Inventory was applied to the first grade students in the research. It was found that the students' achievement in mathematics differs according to their learning styles.

In order to determine whether the difference between existing geometric achievement scores according to learning styles is statistically significant, it was determined that there is no statistically significant difference between achievement score means as a result of one-way variance analysis applied to the data. According to the learning styles and geometry course achievements of high school students, the ANOVA result is given in Table 7.

Table 7. ANOVA Results of the Learning Styles and Geometry Lessons of High School Students

\begin{tabular}{lccccc}
\hline Source of Variance & Sum of Squares & Std. Dev. & Mean of Squares & F & p \\
\hline Between Groups & 426.427 & 3 & 142.142 & .347 & .792 \\
Within Groups & 18849.753 & 46 & 409.777 & & \\
Total & 19276.180 & 49 & & & \\
\hline
\end{tabular}

Note. Std. Dev. $=$ Standard Deviation, $F=$ ANOVA value, $\mathrm{p}=$ Significance Level , $\mathrm{P}>0,05$

\subsection{The Third Sub-question of the Research was expressed as "Is there a Statistically Significant difference between Geometry Course Achievements of High School Students according to Gender?"}

The distribution of the students' geometric achievement means according to gender is given in Table 8 .

Table 8. The Distribution of the Students' Geometric Achievement Means According to Gender

\begin{tabular}{lcccccc}
\hline Gender & $\mathrm{n}$ & $\overline{\mathrm{x}}$ & $\mathrm{Sd}$ & $\mathrm{Se}$ & $\mathrm{t}$ & $\mathrm{p}$ \\
\hline Male & 20 & 51.750 & 14.167 & 3.167 & 5.428 & .000 \\
Female & 30 & 76.466 & 16.745 & 3.057 & & \\
\hline
\end{tabular}

Note. $\mathrm{n}=$ Sampling number, $\overline{\mathrm{x}}=$ Mean, $\mathrm{Sd}=$ Standard Deviation, $\mathrm{Se}=$ Standard error, $\mathrm{p}=$ Significance Level $\mathrm{p}<0,05$

As a result of the t-test analysis applied to the data in order to determine whether the were statistically significant according to gender, it was determined that there was a statistically significant difference according to the gender. The t-test result of high school students' geometry achievement score means according to gender is given in Table 8. In Table 8, when the students' geometry achievement score means are analyzed according to gender, it is seen that the achievement mean of female students is higher than the achievement mean of male students and that female students are more successful in geometry lesson. In this study, which shows statistically significant difference in the students' geometry achievement score means according to gender in favor of females, it was determined that female students learned geometry lessons better than male students. Duatepe Paksu (2013) 
investigated classroom teacher candidates in terms of their readiness in geometry subjects, geometry thinking levels, geometry self-sufficiency and geometry attitudes. It was found in the study that readiness of female teacher candidates in the geometric bodies, plane and circle is higher than male teacher candidates. Similarly, Taşdemir and Taşdemir (2008) found that the mathematical achievement of primary school students was higher in favor of girls. In the study conducted by the California Assessment Program, it was found that girls are more successful than boys in primary school years (Huetinck and Munshin, 2000).

3.4 The Third Sub-question of the Research was expressed as "What are the Opinions of Math Teachers about Learning Styles?"

Qualitative data was tried to be compiled from face-to-face interviews with mathematics teachers. The views of mathematics teachers are presented below.

"I have heard the concept of learning style for the first time in this study." (Teacher A)

"In my geometry classes, I do not teach lessons by taking individual differences into consideration. The physical structure of the class is an obstacle to this. I use the materials necessary for students to learn." (Teacher B)

"I knew that each student had different levels of learning. I've heard the learning style for the first time. I think I address the whole class by preparing different materials for geometry lessons." (Teacher C)

The teachers who participated in the research stated that they they had heard learning styles for the first time. In their geometry classes, the teachers stated that they did not consider the learning style of the students.

\section{Conclusions, Discussion and Suggestions}

As a result of the research, it was determined that the learning styles of the students differ. It was determined that teachers do not take the learning styles that are one of the individual differences into consideration in the classroom environment. It is thought that the education made by thinking that the students learn in the same way will not provide any benefit.

Within the scope of this study, recommendations related to learning styles can be as follows;

1. It can be said that learning styles has not been taken into consideration; that taking learning styles into consideration geometry lessons will increase the efficiency of teaching geometry.

2. It is believed that learning styles have unique features for each, and it is believed that knowing these characteristics will be beneficial for students, teachers and parents.

3. Examining the change in the student's learning style at certain times of the teaching and learning period can be useful in determining the learning environments.

This study, examining geometry course achievement according to learning styles, can be carried with a wider group of students. The examination of the effects of learning styles in learning geometric concepts that are not covered in this study at primary and high school level is recommended.

\section{References}

Aşkar, P., \& Akkoyunlu, P. (1993). Kolb Öğrenme Stili Envanteri, Eğitim ve Bilim; sayl, 87, 37- 47.

Boydak, A. H. (2008). Öğrenme stilleri. İstanbul: Beyaz.

Duatepe Paksu, A. (2013). Sınıf öğretmeni adaylarının geometrik yapılara ilişkin çizim becerilerinin incelenmesi. Kastamonu Eğitim Dergisi, 21(3), 827-840.

Gülten, D., \& Gülten İ. (2003). Lise 2. Sınıf Öğrencilerinin Geometri Dersi Notları İle Öğrenme Stilleri Arasındaki İlişsi Üzerine Bir Araştırma, Eğitim Araştırmaları Dergisi, 16, 74-87.

Güven, G. (2003). Fizik Öğretiminde Öğretmen Adaylarının Öğrenme Stillerinin Araştırılması,Yüksek Lisans Tezi, Marmara Üniversitesi, Fen Bilimleri Enstitüsü, İstanbul.

Huetinck ve Munshin (2000). Teaching Mathematics for the 21st Century. Upper Saddle River, New Jersey Colombus, Ohio.

Kaya, R. (1985). Matematik Öğretiminde Yöntem, Bildiri, Türk Eğitim Derneği III. Öğretim Toplantıs1, Ortaöğretim Kurumlarında Matematik Öğretimi ve Sorunları, (pp. 178-186). Türk Eğitim Derneği Yayınları, 237s. Yay. Haz: Nurettin Ergen.

Kolb, D. A. (1984). Experiental Learning: Experiences as the Source of Learning and Development, Englewood Cliffs, NJ: Prentice Hall, INC.

Kolb, A. Y., \& Kolb, D. A. (2005). Learning styles and learning spaces: Enhancing experiental clearning in 
higher education. Academy of Management Learning \& Education, 4(2), 193-212.

Merriam, S. B. (2013). Nitel Araştırma Desen ve Uygulama Iç̧in Bir Rehber, (Çev.Editörü: Selahattin Turan). Ankara: Nobel Yayınları.

NTCM, (2000), Curriculum and Evaluation Standarts for School Mathematics, Online.

Peker, M. (2003). Kolb Öğrenme Modeli. Milli Eğitim Dergisi, sayı, 157.

Peker, M. (2005). İlköğretim Matematik Öğretmenliğini Kazanan Öğrencilerin Öğrenme Stilleri ve Matematik Başarısı Arasındaki İlişki, Eğitim Araştırmaları, S. Bahar, Sayı, 21.

Taşdemir, M., \& Taşdemir, A. (2008). A Comparison of Turkish Primary School Students' Achievement in Science and Maths Subjects. Journal of Qafqaz. University, 22(2), 190-198.

TDK (2005). Türk Dil Kurumu Sözlüğü, Ankara: TDK.

Yıldız, H. (2011). Öğretim ilke ve yöntemleri (VI. Bölüm). İstanbul: İdeal Kültür ve Yayıncılık.

\section{Copyrights}

Copyright for this article is retained by the author(s), with first publication rights granted to the journal.

This is an open-access article distributed under the terms and conditions of the Creative Commons Attribution license (http://creativecommons.org/licenses/by/4.0/). 